\title{
Teaching Turkish as a Foreign Language with Interactive Whiteboards: A Case Study of Multilingual Learners
}

\author{
Murat Şengül $^{1}$ • Yalın Kılıç Türel ${ }^{2}$
}

Published online: 30 December 2017

(C) The Author(s) 2017. This article is an open access publication

\begin{abstract}
This study attempts to explore the effects of interactive whiteboard (IWB) technology use on students' achievement and perceptions in Turkish as a foreign language instructional context. The participants included 19 Nigerian Turkish Language learners who were all fluent in three languages: English, Hausa, and their tribal languages. They had been learning Turkish for the last four months when they began the study using an IWB in their Turkish writing classes. For the 14-week study, participants were exposed to the IWB instruction for six hours per week. Overall implementation took place in a Turkish Language Learning Research Center in a state university in Turkey. We have collected the data via the Interactive Whiteboard Survey for University Students, achievement tests as well as semi-structured interviews with students to support quantitative data after the implementation $T$-tests and descriptive statistics were used for the analysis of the survey and content analysis for the interview data by using, QSR Nvivo 8.0, a qualitative data analysis tool. Results revealed that participants developed positive attitudes towards the IWB use and were satisfied with the contributions of IWB use in their language classes such as writing and grammar.
\end{abstract}

Keywords Interactive whiteboard · Turkish language learning · Instructional technology $\cdot$ Higher education $\cdot$ Student perceptions

Murat Şengül

msengul2323@ hotmail.com

1 Department of Turkish Language Education, Nevşehir Hacı Bektaş Veli University, Nevşehir, Turkey

2 Department of Computer Education and Instructional Technologies, Firat University, Elazig, Turkey 
Today, researchers from various disciplines are seeking alternative ways and solutions of using information and communication technology (ICT) to achieve more effective, interactive, and enjoyable instruction in schools (Hall and Higgins 2005; Smith et al. 2005; Türel 2010). Interactive whiteboard (IWB), as an ICT, has been a growing trend to design more interactive learning environments in many disciplines including language learning (Tozcu 2008). Educators and researchers (e.g., Cutrim-Schmid 2006, 2010; Durán and Cruz 2011; Gray et al. 2005; Mathews-Aydinli and Elaziz 2010; Tozcu 2008) have been conducting researches on the use of IWB in foreign language teaching particularly in the last decade. IWBs are touch-sensitive boards mostly used in conjunction with a computer and a projector. IWBs enable instructors and students to use and manipulate digital content during instruction. Many studies address the contributions of IWBs to instruction as well as students' learning and motivation in school settings (Bell 2002; Levy 2002; BECTA 2003; Brown 2003; Beauchamp and Parkinson 2005; Cutrim-Schmid 2006, 2010; MathewsAydinli and Elaziz 2010; Smith et al. 2005; Türel 2010, 2011a, b; Türel and Demirli 2010; Xu and Moloney 2011a; Çelik 2014).

Achieving the higher order benefits from this technology depends on the context in which IWBs are used (Cutrim-Schmid 2010). Considering the appropriate features of IWBs, the instructor can design a learning environment where students can be actively involved in the learning process and construct their own knowledge (Beeland 2002; Türel 2010, 2011b). In such settings, the audio-visual media on the IWB may help particularly language learners improve various skills such as reading, writing, and understanding since they can see, hear and touch the material on the IWB, which is essential for students' cognitive and affective learning (Březinova 2009; Koster et al. 2013; Türel 2010; Xu and Moloney 2011a, b).

With an effort to design such a learning environment, we have attempted to explore the use of IWBs on learning Turkish as a foreign language in higher education context.

\section{Literature Review}

Despite many studies having examined the IWB use in schools, there is a lack of research focusing on the use of IWBs in foreign language programs (Albaaly and Higgins 2012; Cutrim-Schmid 2006, 2010; Durán and Cruz 2011; Glover et al. 2007; Mathews-Aydinli and Elaziz 2010; Tozcu 2008). Many studies have focused on the use of IWBs in language teaching setting where English is taught as a foreign language (EFL) context. There is a need to investigate the use of IWBs in teaching languages other than English. In this context, no studies were found related to the use of IWB for Turkish as a foreign language.

In a recent experimental study where writing micro-skills taxonomy was used, Albaaly and Higgins (2012) investigated the effects of IWBs on Egyptian students' achievement in EFL writing courses in medical schools and found no difference between the control and experimental groups in terms of achievement tests scores. Surprisingly, this finding is not parallel with the existing studies that stress the potentials of IWBs for language learning (Albaaly and Higgins 2012).

With an effort to developing a framework regarding IWB use in an EFL program, Cutrim-Schmid (2006) has conducted a qualitative research grounded on the critical theory of technology that basically defends the needs for technology for educational contexts. As a result of that study whose participants were university students coming from various countries for the EFL program, she has delineated some of the emerging factors related to the IWB use following as the inherent characteristics of the technology, students' and 
teachers' beliefs and understandings of the technology (Cutrim-Schmid 2006). Regarding IWB use in EFL classes, Cutrim-Schmid (2010) has also focused on developing EFL teachers' IWB competencies in secondary schools and suggested that teachers had to have three main competencies: (a) IWB material design, (b) facilitating of interaction with an IWB, and (c) balancing use of IWB.

In their study, Durán and Cruz (2011) used IWBs to examine English learning of primary school students within four main skills (reading, writing, speaking and listening). Researchers collected data through observation records and questionnaires. They found that the IWB was a special tool that draws students' attention in an exceptional way and positively affected the quality of interaction among students. Teacher participants also declared that the use of IWBs helped develop the learning process and saved time despite the difficulties of appropriate design of materials.

In another study, Glover et al. (2007) observed teachers' pedagogy with IWBs in 16 modern languages courses (French, German, and Spanish) in UK secondary schools. Findings of this study demonstrated that although teachers mainly used the teacher-centered approach, they achieved an enhanced interaction by means of the IWB over time (Glover et al. 2007). In an original study from USA, Tozcu (2008) has surveyed the IWB uses of 75 instructors teaching non-Latin (Hindi, Pashto, Dari, Persian, and Hebrew) alphabets. Stressing the difficulty of learning different shapes and places of the letters in these alphabets, instructors considered IWB as an effective instructional tool to teach nonroman scripts (Tozcu 2008).

One of the most comprehensive studies conducted by Mathews-Aydinli and Elaziz (2010) in Turkey which includes perspectives of teachers and students about IWB use in EFL classes from primary to graduate schools as well as private English courses, researchers collected data by means of two questionnaires (one student and one teacher questionnaire) that they developed in both Turkish and English languages and provided only Cronbach Alpha reliability coefficients. According to the results of this study, students emphasized that the IWB was a motivating, engaging, and an easy-to-use tool, which facilitated their learning; however, they experienced several technical issues such as IWB breakdowns and calibration issues during instruction (Mathews-Aydinli and Elaziz 2010).

Based on the literature review, we have found some limitations: (1) many researchers focused on English as a foreign or second language. There is a limited number of studies in which other languages were used as a second language. (2) While most of the studies were conducted in K-12 educational context, a few were conducted in higher education context. (3) As a research method, observations of ELL classrooms and surveys were dominant. In addition, we identified that those studies only used the survey method and did not provide sufficient detail regarding the validity and reliability of the measurement tools (i.e., Mathews-Aydinli and Elaziz 2010). As Cutrim-Schmid (2006) emphasized, many researchers raise the issue that using quantitative research approach alone for CALL studies may be an impediment to draw a big picture of the phenomenon. In her recent study, Cutrim-Schmid (2016) defines the IWB as a professional development tool which supports language teachers and puts forward the principles and theories relating language teaching strategies by means of IWBs to facilitate learning of the second language. Despite the clear description of how to support IWB based language learning with appropriate theories, there is a crucial need for conducting more practical implementations of suggested theories.

Attempting to fill the gap in the existing literature regarding IWB use in the foreign language learning, we aimed to investigate learners' achievements and their perceptions about using an IWB in a Turkish foreign language course. We believe that there are several 
prominent features that make our study strong in terms of study design. For example, this is the first study that examines the IWB use in Turkish as a foreign language. In addition, this study has used qualitative supported quantitative research design in which data are collected by means of a valid and reliable IWB student survey as well as semi-structured interviews with students. Another prominent feature of the current study is that aiming to examine learners' general perceptions about IWB use in a foreign language learning program instead of focusing on a particular aspect such as non-roman scripts (Tozcu 2008) and English writing micro-skills (Albaaly and Higgins 2012). Moreover, the implementation period of this study can be regarded as long enough (14-weeks) to enable students to develop an attitude towards IWB use by tearing off the initial enthusiasm regarding using of a new technology described as the novelty effect (Beauchamp and Parkinson 2005; Levy 2002). Another essential characteristic of the study is that recruiting a particular group of multilingual participants for foreign language program as we provide more details under methods section.

Considering the needs for conducting more research on the use of IWB technology in language learning and limitations of existing studies in the field, we aim to explore the perceptions of students about the use of IWBs in terms of the contributions of IWBs to teaching and learning practices, and students' motivation as well as the usability of IWBs in a Turkish as a foreign language program.

\section{Methodology}

\subsection{Research Design}

In accordance with the purpose of this exploratory study and the possibilities of the context, we have adopted pre-experimental research design approach, which is regarded as a cost-effective way to explore the potential of an implementation or treatment for further investigations (Campbell and Stanley 1967). Since there was no control group in this study due to the limited number of participants $(\mathrm{N}=19)$, we have followed two types of preexperimental design methods called a "one-shot case study" and one group pre-test and post-test design. Campbell and Stanley (1967) suggest that a "one-shot case study" has several threats in terms of internal validity, such as maturation, testing, and regression effects due to the lack of control group; however, it helps researchers to explore the current situation or phenomenon, which is vital for underpinning the future experimental studies. As well as the one-shot study design, we have also considered one group pre-test and posttest design for students' achievement.

To have a better understanding of the quantitative data results, we have collected the qualitative data via semi-structured interviews with volunteer students. Thus, we had an opportunity to provide a deeper analysis into the data by considering the students' ideas and perceptions with their own statements. We have followed the content analysis procedures for the collected qualitative data to make an interpretative inquiry. The themes for the data collected in this study were created mainly based on the literature. Before the final solution of the categorization of themes, we took the approval of two experts' views in the field of language instruction and instructional technology. 


\subsection{Participants}

This study included 19 Nigerian students who were in a Turkish language learning program, which lasted eight months and two semesters (fall and spring) in Turkey. All of the participants were male and their mean age was 19.2 years $(\mathrm{SD}=2.35)$. Participants had no previous experience with the IWB. When they started to be taught with an IWB at the beginning of second semester, their Turkish Language was typically B1 (Threshold) level according to the European Language Portfolio standards.

\subsection{Information About Participants' Existing Language Knowledge}

Participants began the Turkish Foreign Language program in the fall 2009 semester in a state university in the middle-eastern part of Turkey. The aim of this language program is to teach Turkish to students to a level adequate for following their courses in their undergraduate program (i.e., Mathematics Education, Science Education, Software Engineering, Electrical Engineering, Mechatronics Engineering, Chemistry, and Nursery) before they begin. That years' program was interesting since it hosted merely 19 students from the same country (Nigeria). In other words, all of them were coming from the same culture; thus, the program was modified based on this situation. In addition, all students had a lot of experience in language learning, which is unusual for most language learners since they were already fluent in three languages: English, Hausa (a Chadic language spoken in Nigeria), and their tribal languages. Hausa and tribal language, which are commonly used by participants, are branches of the Afro-asiatic language family (Greenberg 1960). English, a member of Indo-European language family, is the official language in Nigeria. On the other hand, Turkish is an agglutinative Ural-Altaic language, which has different phonetics and structural characteristics (Özyürek 2009). For example, in Turkish, the verb is at the end of sentence and there are a number of suffixes. Although it might be very hard to learn for students who are not familiar with this type of language structure, many people in the world are increasingly learning and speaking Turkish (Özyürek 2009).

\subsection{Issues Faced During the Process}

During the program, in which the study was carried out, the complex structure of Turkish had been a big challenge for participants; thus, the instructors, when necessary, had to use English as the common language to communicate with students and to overcome this complexity by showing grammatical similarities and contrasts between Turkish and English.

By the time we began the implementation, students had completed their first five months in their intensive Turkish as a foreign language program. During a 14-week period, students have attended the courses that taught with an IWB at least six hours per week. In this process, the instructor has tried to use a variety of instructional strategy convenient with IWBs. Specifically, Meskill and Anthony (2014) stated that in classes where visual instructional strategies by means of technologies is employed, instruction needs to be enriched with annotations, questions, and individual student and whole-class observations in order to maintain learner motivation. In this study, the instructor benefitted from these strategies to increase the effectiveness of IWB and gain learners' attention. For example, the instructor used famous novels and fairy tales from World's classics (i.e., Jack and the Beanstalk, Beauty and the Beast, Tale of a Forest) and Turkish's classics (i.e., Yoksul 
Kunduraci "Poor Shoemaker", Anadolu'da Bahar "Spring in Anatolia") for listening and reading classes as well as excerpts from them for writing and grammar activities. Digital versions of these tales and stories (with image and audio support) were played on the board and students could annotate what they heard or understood regarding the content. Instructor and students could also explain, highlight or draw the vocabulary, phrases, and idioms in the materials via an IWB and discuss on them. Moreover, the instructor has pulled some passages out existing novels, tails, and poems and encouraged students to complete the parts that are missing. Similarly, the instructor used the text that includes grammatical errors and typos, then, had students find and correct these errors on the board (see Fig. 1). In addition, the instructor designed PowerPoint slides and imported them to the IWB software. Those slides included the picture and notes section on each screen. Then, students, in groups, wrote appropriate comments about the pictures on the board and discussed their points with other groups. In all of these activities, the intention was to increase active involvement of the students in the learning process by facilitating interaction between students and the instructional content on the IWB as well as interaction among students as suggested by researchers (i.e., Beauchamp and Parkinson 2005; Moore 1989; Smith et al. 2005; Türel 2010) in order to achieve an effective IWB use.

To conclude, considering the suggestions given by educational researchers and instructional designers, we designed an interactive learning environment in which students can actively participate in the learning process and construct their own knowledge.
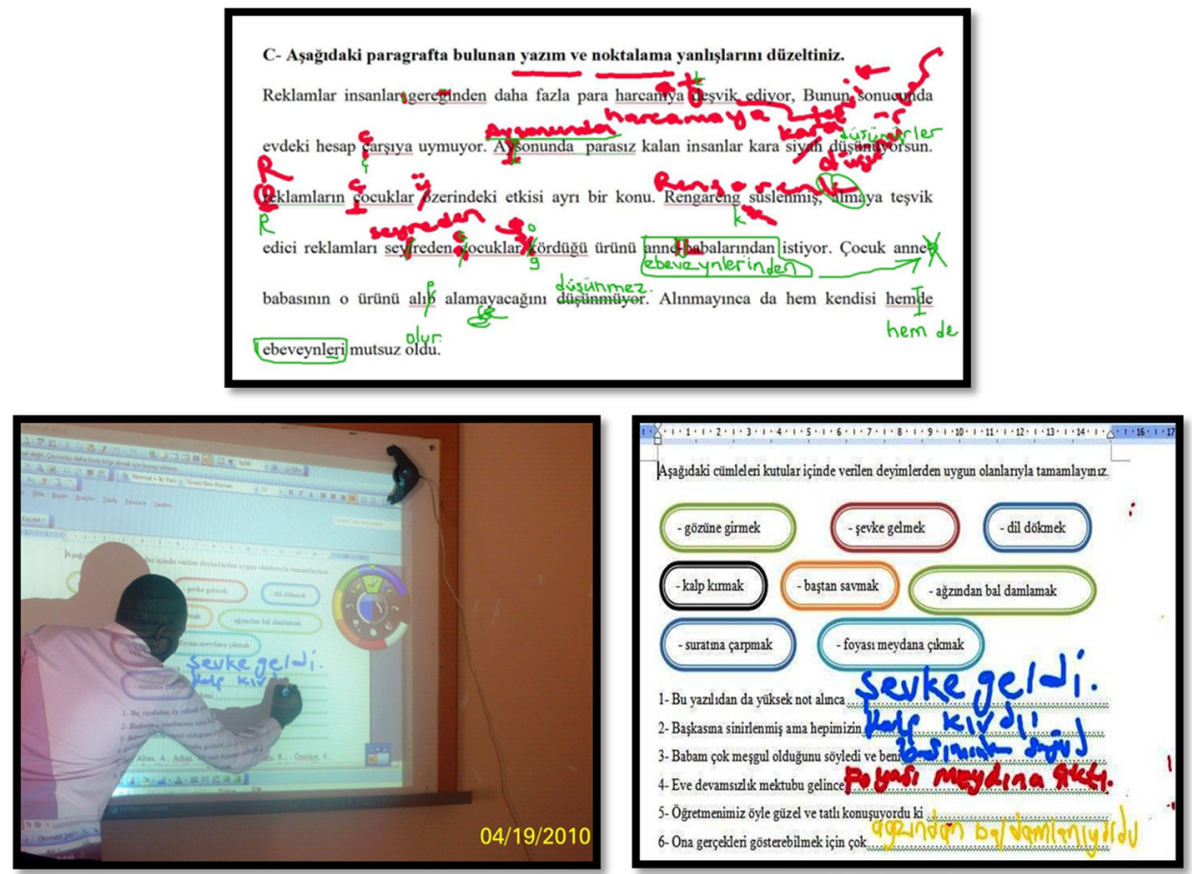

Fig. 1 Sample materials used during the program 


\subsection{Data Collection and Analysis}

In this study, we used two measurement tools to examine effects of IWB use on students' perceptions and their achievement. In addition, we have designed an interview protocol, which includes questions regarding the IWB implementation for semi-structured interviews.

The first tool used as pre-test and post-test was the Interactive Whiteboard Survey for University Students (IWBSUS) developed by Türel (2011a) to evaluate perceptions of college students about the use of IWBs in their courses. IWBSUS was built upon the associated studies about the use of an IWB in school settings and technology related models such as TAM (Technology Acceptance Model) suggested by Davis (1989) and Venkatesh and Davis (2000). IWBSUS is an 18-item, 5-point Likert scale $(\alpha=0.92)$, which consists of three factors called as perceived usefulness $(\alpha=0.85)$, perceived learning contribution $(\alpha=0.87)$, and interest and motivation $(\alpha=0.80)$, respectively. Although original form of the survey is Turkish, we also provided the English counterparts of each item to prevent students from the misunderstanding of statements.

Achievement tests (also called proficiency tests), conducted as a pre-test and a post-test, were developed by instructors in the Turkish Language Program by following the Common European Framework (Council of Europe 2002). This framework grounds on the European Language Portfolio, which aims to determine students' competency levels (i.e., C1-Effective Operational Proficiency, C2-Mastery, B1-Threshold, B2-Vantage, A1-Breakthrough, and A2-Waystage) for each language skills (i.e., listening, reading, speaking, and writing). Each proficiency test included a hundred multiple-choice questions after being exposed to pilot analyses in terms of validity and reliability. According to results of pilot analyses, presented in Table 1, we can conclude that both tests have a high level of reliability and a potential to measure individual differences as expected.

We have also carried out semi-structured interviews with seven volunteer participants after IWB implementations to support the results of IWBSUS and achievement test analyses. In students' interviews, we focused on the following themes: (a) students' satisfaction with the use of IWBs, (b) students' and teachers' IWB usage techniques, (c) IWB's perceived usability, advantages, and challenges by students.

Regarding students' perceptions and attitudes about IWB use, we provide descriptive statistics (i.e., means and standard deviations) for each item under three factors of IWBSUS. For the interpretation, we have graded means based on the following criteria: Strongly disagree, 1.00-1.80; disagree, 1.81-2.60; neutral, 2.61-3.40; agree, 3.41-4.20 and strongly agree, 4.21-5.00. On the other hand, we have analysed the Pearson correlation coefficients to see the relationship between students' achievement and their perceptions based on the results of students' IWBSUS scores. In addition, we have performed the

Table 1 Reliability analysis results of achievement tests

\begin{tabular}{lll}
\hline Proficiency test conducted as & Pretest & Posttest \\
\hline Sample (N) & 246 & 317 \\
Mean (M) & 52.08 & 48.45 \\
Standard deviation (SD) & 20.45 & 22.18 \\
Avg. of difficulty (pj) & 0.52 & 0.53 \\
Avg. of discrimination Indexes (rjx) & 0.44 & 0.51 \\
Reliability (KR-20) & 0.83 & 0.89 \\
\hline
\end{tabular}


paired-sample $t$-test to find out whether there is a significant difference between pre-test and post-test achievement scores.

For the analysis of interview data, we created the themes in terms of issues, advantages, disadvantages, and usability of IWBs based on the literature review. Both authors, as raters, have separately coded the statements to provide the validity of the coding schema, and then, calculated the Cohen's Kappa coefficient as 0.85, which means there is a high level of agreement between raters according to Landis and Koch (1977). In the final step of coding, both raters have reached a consensus on disagreed codes. We have proved the associated students' statements under discussion section with the students' interview sequence numbers such as Student-1, Student-2 instead of real names of interviewees.

\section{Results}

In this section, we present our findings regarding students' achievement and the effects of IWB use on students' perceptions.

\subsection{Achievement}

As expected, a paired-sample $t$-test indicated that students' achievement scores were significantly higher for the post-test $(\mathrm{M}=64.64, \mathrm{SD}=8.38)$ than for the pre-test $(\mathrm{M}=50.42, \mathrm{SD}=13.07), t(18)=-7.16, p=0.000, \mathrm{~d}=-1.91$. The Eta squared statistics (0.75) shows a very large effect size for the paired-sample $t$-test (Pallant 2007). Although there is a significant difference between pre-test and post-test scores, it is difficult to suggest that the difference may stem from the use of IWB as is discussed later in this study.

\subsection{Perceptions About IWB Use}

We have examined descriptive statistics of students' responses to each item in the IWBSUS and provided the results as per each factor. Table 2 shows the means and standard deviations for the first factor, Perceived Usefulness of IWBs.

Table 2 Perceived usefulness of IWBs

\begin{tabular}{|c|c|c|}
\hline F1: Perceived usefulness & M & SD \\
\hline Q1. I believe IWB is a useful technology for us to learn & 4.47 & 0.61 \\
\hline $\begin{array}{l}\text { Q2. I believe it is necessary for my teachers to use technology (computer, internet, etc.) in } \\
\text { class }\end{array}$ & 4.21 & 0.79 \\
\hline Q3. IWB can be used for all classes & 3.63 & 1.07 \\
\hline Q4. The IWB helps more effective time management in class & 4.11 & 0.74 \\
\hline Q5. I think that the courses are more efficient with IWB & 4.11 & 0.74 \\
\hline Q6. The IWB helps more effective use of computer and projector & 4.47 & 0.51 \\
\hline Q7. IWB makes the courses more interactive & 3.68 & 0.95 \\
\hline Q8. IWB makes the class more entertaining & 3.84 & 1.39 \\
\hline Total & 4.07 & 0.43 \\
\hline
\end{tabular}


In the first factor, it is apparent that students agreed on the usefulness of IWBs for the language learning courses $(\mathrm{M}=4.07, \mathrm{SD}=0.43)$. Two items ( $\mathrm{Q} 1$ and $\mathrm{Q} 6)$ have the highest point $(M=4.47)$ in this factor (also in overall survey); these items refer to usefulness of IWB and contributions of IWBs to the use of computer and projector in the classroom, respectively.

Second factor addresses the positive effects of IWBs on students' learning (see Table 3) with a higher level of students' agreement $(\mathrm{M}=4.06, \mathrm{SD}=0.53)$.

Although last factor's item-scores are close to the "agree" level $(\mathrm{M}=3.64$, $\mathrm{SD}=0.56$ ), it has the lowest average mean scores of overall survey (Table 4). Particularly, Q18, which basically refers to the lack of students' IWB usage, has the lowest mean score $(\mathrm{M}=3.05, \mathrm{SD}=0.56)$.

\subsection{Correlation Between Students' Achievement and Perceptions About IWB}

According to Pearson correlation analysis, although we found statistical positive moderate correlation between students' achievement scores and their perceived interest and motivation (Factor 3 ) scores $(\mathrm{r}=0.50, p<0.01)$, we did not find any significant correlation between achievement scores and other factors' scores $(p>0.05)$. Calculated coefficient of determination denoted $\mathrm{r}^{2}=0.25$, refers to $25 \%$ common distribution between both variables, which is regarded as a notable value. Similarly, we found a non-significant moderate correlation between students' post-test achievement scores and perceived interest and motivation factor's scores $(r=0.44, p=0.06)$. Coefficient of determination for this analysis was calculated as 0.19 . None significant correlations $(p>0.05)$ for both analyses may be due to small sample size.

\subsection{Analysis of Interviews}

Results of the interview data showed that all students $(f=7)$ were satisfied with the use of IWBs and would like to have IWB assisted courses in the future. Interviewees stated that the use of IWB effectively facilitated their learning $(f=7)$ and motivation $(f=3)$, increased their attention towards the course content $(f=3)$, and made language learning more entertaining $(f=2)$. In addition, three interviewees stressed the positive effects of using World Classic and Turkish Classic novels and fairy tales via IWBs as instructional materials for their language skills. All interviewees also suggested the IWB use for other courses by stressing the advantages for instruction including no need for blackboard $(f=1)$, recording the lecture $(f=2)$, no noise during instruction $(f=3)$ and so on. In

Table 3 Perceived learning contribution

\begin{tabular}{llr}
\hline F2: Perceived learning contribution & M & SD \\
\hline Q9. I think that the courses are more efficient with IWB & 4.16 & 1.02 \\
Q10. I can learn more when my teacher uses an IWB & 4.26 & 0.93 \\
Q11. IWB helps us learn together & 4.05 & 0.78 \\
Q12. IWB helps me learn faster & 4.11 & 0.99 \\
Q13. IWB makes learning more exciting & 3.74 & 1.05 \\
Total & 4.06 & 0.53 \\
\hline
\end{tabular}


Table 4 Interest and motivation

\begin{tabular}{lll}
\hline F3: Interest and motivation & M & SD \\
\hline Q14. I believe that if my teachers use IWB more often, I will enjoy lessons more & 3.89 & 0.94 \\
Q15. I feel comfortable when IWB is being used & 4.32 & 0.67 \\
Q16. IWB increases my attention towards the course & 3.42 & 1.02 \\
Q17. IWB increases my motivation towards the course & 3.53 & 0.84 \\
Q18. I look forward to my teacher's using IWB in class & 3.05 & 1.31 \\
Total & 3.64 & 0.56 \\
\hline
\end{tabular}

addition, all interviewees diversely emphasized their positive attitudes about the use of IWBs and expectations of the IWB use for their future courses. Paying attention to easy-touse nature of IWBs $(f=5)$, all interviewees also stressed that IWBs can effectively assist activities in terms of reading, writing, and grammar skills in Turkish; however, three students said that there was no need to use an IWB in speaking and listening activities. All interviewees expressed that they had an opportunity to use the IWB during instruction while two of them noted that they had not used it sufficiently.

Regarding the disadvantages of the IWB use, four students clearly stated that there was no disadvantage of IWBs while noted the stylus (electronic IWB pen) issues and user problems mostly stemming from the lack of knowledge and skills concerning the use of this new technology. Two interviewees also mentioned that IWBs caused less workload for their instructor since the instructor used existing materials on the board without giving traditional lecture.

According to the interviewees' responses, the instructor used the several IWB techniques with both individual and group activities including answering the questions on the board $(f=2)$, completing sentences $(f=5)$ (in Writing class), correcting the grammatical errors (see Fig. 1) in the text $(f=6$ ), and writing what you heard (in Listening class) on IWB $(f=2)$.

\section{Discussion}

Many studies clearly reveal the positive effects of IWB use on students' achievement in foreign language learning (Gérard and Widener 1999; Gray et al. 2005; Cutrim-Schmid 2006; Xu and Moloney 2011a, b). In parallel with the results of these studies, we found a significant difference in terms of achievement, which may be considered as an important indicator of positive effects of the IWB use.

Even though various researchers (i.e., Bell 2002; Gray et al. 2005; Swan et al. 2008) have considered a number of variables that have an impact of students' achievement in IWB-oriented studies, there are also some issues including maturation and time, which should be regarded as the influential factors particularly in the field of foreign language learning (Nagle 1999; Trivett and Skillen 1998). Consequently, we believe that we cannot make a big claim about the significant achievement improvement arising from the IWB use due to the lack of control group in this study. However, we have attempted to support this finding with perceptions of students regarding the contributions of IWB use to learning and 
achievement as recommended by previous studies (i.e., Mathews-Aydinli and Elaziz 2010; Albaaly and Higgins 2012).

In other words, we believe that positive perceptions of students about the effects of IWB implementation in terms of their learning and motivation, and the usability of the technology may help us surmise the success of the IWB implementation and, then, students' achievement. In terms of the relationship between students' achievement and their perceptions about the IWB use, we have found only a positive correlation between students' achievement scores and their interest and motivation factor's scores. We think that this factor mainly addresses students' attitudes and feelings about the IWB use, which is directly proportional to the students' achievements.

Students' overall scores from IWBSUS reveal that students' were satisfied from the use of IWBs in their classes $(\mathrm{M}=3.95, \mathrm{SD}=0.37$ ). Türel (2011a) suggests the IWBSUS as one of the most practical tools to measure student's perception about IWB use, which was developed on grounds of Davis' (1989) Technology Acceptance Model (TAM). According to this model, the success, sustainability, and effectiveness of an instructional technology basically depend on the acceptance of individuals who have an experience about the use this technology (Davis 1989). TAM attempts to measure users' acceptance or adoption of the technology by their perceptions in terms of the usefulness, easy-of-use, and intention to use of the technology as well as positive attitudes and satisfaction about the use of technology (Davis 1989; Venkatesh and Davis 2000). Thus, results from both IWBSUS and interview data analyses clearly indicate a high level of students' acceptance and satisfaction of the IWB as an effective and useful technology for language learning classes in parallel with the findings of similar studies (Albaaly and Higgins 2012; Cutrim-Schmid 2006; Glover et al. 2007; Mathews-Aydinli and Elaziz 2010).

Students have mostly accepted $(\mathrm{M}=4.47, \mathrm{SD}=0.61)$ that IWB was a useful technology for their learning (Q1). Regarding this issue, Student-2 stated that

It was easy for me to learn with an IWB. For example, you may forget what you learned just after the class or you may not clearly understand what the teacher meant. In both cases, you can go through the recorded lessons at home and understand the subject very well. That's, it was so helpful for me.

Another student (Student-1) has also expressed his feelings about the IWB like

Honestly, I like interactive whiteboard so much... I can learn better with IWB and that would be great if IWB could have used in all courses...

In terms of the effectiveness of IWBs, students strongly agreed $(\mathrm{M}=4.47, \mathrm{SD}=0.51)$ that IWBs increase the efficiency of computer and projector use in class (Q6). Considering the benefits of ICT and overall efforts to provide a successful ICT integration in foreign language learning, we considered this finding rather meaningful. Türel (2010, 2011a) stressed the importance of how to use/integrate IWBs in learning settings. For example, using famous and traditional novels as IWB materials could be considered an effective strategy to enhance students' various language skills, as three students stated during interviews the positive effects of using novels. Durán and Cruz (2011) carried out the same strategy in their EFL study and attained similar reactions from their participants.

As maintained by Davis (1989), we know that the perceived usability of an instructional technology is an essential indicator in terms of the usefulness (and acceptance) of the technology. That's why; many studies (Beeland 2002; Glover et al. 2007; Mathews-Aydinli and Elaziz 2010; Türel 2011a, b) have attempted to explore users' actual behaviours and attitudes about the usability of IWBs rather than focusing on the outcomes of IWB use. 
In our study, both IWBSUS and interview forms included questions referring the usability issue. While participants agreed or strongly agreed (i.e., Q3, Q9, Q14) on the vitality and efficiency of IWBs for foreign language learning classes, interview data have disclosed more sense about the usability of IWBs. Interestingly, only two of seven interviewees (Students 5 and 6) mentioned that IWB could be used any foreign language learning courses including Reading, Writing, Speaking etc. Moreover, Student-5 said that "IWB can be used any time and place in which a traditional board (blackboard) could be used." Considering their prospective undergraduate programs, students stressed that IWBs could be used in their future courses such as General Chemistry (Student-5), Differential Equations (Student-2). Besides, students have mentioned about their future plans in regard to the learning and teaching with an IWB. For example, Student-7 said

Hopefully, I will be a teacher in Nigeria. There is no interactive whiteboard over there but I will buy one and teach my courses better. I will certainly use an IWB in my classes.

Smith et al. (2005) suggest that IWB can be used for any type of courses and subjects to the extent of the teachers' knowledge and skills regarding the design of an effective instruction with an appropriate IWB use. Taking into account the various benefits of IWBs, we can conclude that IWBs can be used for the improvement of diverse language skills (i.e., reading, writing, speaking) as Březinova (2009) suggested. However, three interviewees (Students 1, 2, and 3) have explicitly declared that the IWB use might not be convenient for speaking and listening classes. Similar studies (i.e., Gray et al. 2005; Xu and Moloney 2011b) address that students may prefer being more active and; thus, not prefer using an IWB in such practices (i.e., speaking). Since, in this study, the instructor mainly used the IWB in writing and grammar classes, students could not have a chance to interpret different IWB implementations in their writing and listening classes. We still believe that the IWB may even facilitate students' listening and speaking skills when instructors select the appropriate IWB strategies in these classes. For example, a teacher can use any type of materials (text, picture, audio, video etc.) on the IWB to initiate discussions and encourage students to actively and collaboratively participate into discussions (Beauchamp and Parkinson 2005; Smith et al. 2005; Türel 2010). Moreover, students can share their views and comments (by annotating) with their friends and manipulate (by highlighting, coloring etc.) the instructional content by means of an IWB. Such social interactions can play an essential role for learners in improving their language skills.

Moreover, Gray et al. (2005) pointed out students' desire to be more active during instruction. In order to improve language skills such as speaking, it is apparent that instructors have to facilitate student's active participation individually and collaboratively, which is also viable for any instructional context (Smith et al. 2005; Xu and Moloney 2011a). By supporting the idea of the need for students' active involvement in the learning process, Q18, "I look forward to my teacher's using IWB in class", had the lowest score $(\mathrm{M}=3.05, \mathrm{SD}=1.31)$ in this study. Based on our understanding, students' neutrality may stem from their willingness about using the IWB themselves instead of their instructor. Many studies (i.e., Smith et al. 2005; Türel 2011b) emphasize that teachers excessively use the IWB as a presentation tool during their lecture and do not allow their students sufficiently use the IWB themselves. For example, Orr's study (2008) shows us only $4 \%$ of all students were allowed to use an IWB themselves in their classes. From the constructivist perspective, students' active involvements are regarded as a crucial component for the construction of knowledge by learners (Brooks and Brooks 1999; Türel 
2011b). Thus, it is essential for particularly foreign language instructors to design a learner-centered, constructivist instructional environment in which students can actively use the IWB. In addition, overuse and misuse of the IWB by teachers may lead to a decrease on students' motivation and attention (Hall and Higgins 2005). Regarding this issue, one student commented that

IWB make teachers job easier, they can use the existing materials on the board and do not have to lecture much. However, one way presentations over those ready-made materials might be boring for us (Student 3).

In addition to above-mentioned problem, two students (Student 3 and 5) made comments about the stylus problems and one student said that they had only experienced a couple of technical issues at first and then they could cope with such problems as they became familiar with the IWB. Considering these common issues, we can conclude that there were not serious problems regarding the IWB use during implementations, which is basically regarded an expected and satisfying result for this study.

\section{Conclusions and Suggestions}

This study explores the effects of the IWB use on students' perceptions and their achievements in the context of Turkish as foreign language. Results show that students were satisfied with the use of an IWB in their classes and believed in the contributions of IWBs to their learning and motivation. Due to the nature of foreign language learning context, students' needs and desires to be more active and to interact more with their peers and the materials come into prominence according to results of the study.

This study has several distinctions in terms of its context and participants. For example, it has been the first study examining the IWB use in Turkish as a foreign language program. Since the participants are multilingual and have a special experience in language learning, their positive attitudes and perceptions about the IWB technology seem noteworthy in terms of the evaluation of the IWB use in foreign language learning. There are a number of language learning centers that accept students from all over the world. Considering the distinct and difficult structure of Turkish language, those centers should take account of using technology such as interactive whiteboards. As for implications of this study, we suggest that teachers who are dealing with teaching a foreign language such as Turkish should benefit from interactive whiteboards for main language skills (i.e., reading, speaking, and writing). Finally, using famous and traditional novels with IWBs enables teachers to use a variety of instructional strategies such as in-class reading, correcting grammatical errors and punctuation in the passage, discussing idioms and vocabulary, dragging-dropping activities, and so forth. Through these activities, it has been possible to increase students' engagement and involvement in learning a new language.

This study also has some limitations that might be an opportunity for the future researchers. Due to the small sample size, we could not assign students to control and experiment groups and thus, we could not have a better understanding of IWBs' actual contributions to students' achievement and perceptions. However, we think that we have provided a solid exploratory study for the future experimental studies. In addition, future studies regarding the effects of the IWB use can focus on the particular groups of Turkish language learners who have diverse mother tongues as well as variables such as anxiety level in Turkish language learning. Such studies may help us have a better 
understanding and interpretation of the positive results of IWB use, which was introduced in this study.

Open Access This article is distributed under the terms of the Creative Commons Attribution 4.0 International License (http://creativecommons.org/licenses/by/4.0/), which permits unrestricted use, distribution, and reproduction in any medium, provided you give appropriate credit to the original author(s) and the source, provide a link to the Creative Commons license, and indicate if changes were made.

\section{References}

Albaaly, E., \& Higgins, S. (2012). The impact of interactive whiteboard technology on medical students' achievement in ESL essay writing: An early study in Egypt. The Language Learning Journal, 40(2), 207-222. https://doi.org/10.1080/09571736.2010.543953.

Beauchamp, G., \& Parkinson, J. (2005). Beyond the 'wow' factor: Developing interactivity with the interactive whiteboard. School Science Review, 86(3), 97-103.

BECTA (2003). What the research says about interactive whiteboards. Retrieved from http://partners.becta. org.uk/page_documents/research/wtrs_whiteboards.pdf.

Beeland, W. D. (2002). Student engagement, visual learning and technology: Can interactive whiteboards help? In Paper presented at the meeting of Annual conference of the association of information technology for teaching education, Trinity College, Dublin.

Bell, M. A. (2002). Why use an interactive whiteboard? A baker's dozen reasons! Teachers.Net Gazette. Retrieved from http://teachers.net/gazette/JAN02/mabell.html.

Březinova, J. (2009). Interactive whiteboard in teaching English to young learners. Unpublished master thesis. Masaryk University, Brno, Czech Republic.

Brooks, J. G., \& Brooks, M. G. (1999). In search of understanding: The case for constructivist classrooms. Alexandria: American Society for Curriculum Development.

Brown, S. (2003). Interactive whiteboards in education. Joint Information Systems Committee Technology Centre. Retrieved from http://www.jisc.ac.uk/uploaded_documents/Interactivewhiteboards.pdf.

Campbell, D. T., \& Stanley, J. C. (1967). Experimental and quasi-experimental designs for research. Chicago: Rand McNally.

Çelik, S. (2014). Exploring IWB use for language instruction in Turkish higher education settings. In E. Cutrim-Schmid \& S. Whyte (Eds.), Teaching languages with technology: Communicative approaches to interactive whiteboard use (pp. 182-205). London: Bloomsbury.

Council of Europe. (2002). Common European framework of reference for languages. Strasbourg: Cambridge University Press.

Cutrim-Schmid, E. (2006). Investigating the use of interactive whiteboard technology in the English language classroom through the lens of a critical theory of technology. Computer Assisted Language Learning, 19(1), 47-62. https://doi.org/10.1080/09588220600804012.

Cutrim-Schmid, E. (2010). Developing competencies for using the interactive whiteboard to implement communicative language teaching in the English as a foreign language classroom. Technology, Pedagogy and Education, 19(2), 159-172. https://doi.org/10.1080/1475939X.2010.491218.

Cutrim-Schmid, E. (2016). Interactive whiteboards and language learning. In F. Farr \& L. Murray (Eds.), Routledge handbook of language learning and technology (pp. 281-295). London: Routledge.

Davis, F. D. (1989). Perceived usefulness, perceived ease of use, and user acceptance of information technology. MIS Quarterly, 13(3), 319-340.

Durán, A., \& Cruz, M. (2011). The interactive whiteboard and foreign language learning: A case study. Porta Linguarum, 15, 211-231.

Gérard, F., \& Widener, J. (1999). A SMARTer way to teach foreign language: The SMART Board ${ }^{\mathrm{TM}}$ interactive whiteboard as a language learning tool. In Paper presented at SITE 99 Conference, North Carolina. Retrieved from http://www.swsc.org/16331056134949507/lib/16331056134949507/A_ SMARTer_Way_to_Teach_Foreign_Language.pdf.

Glover, D., Miller, D., Averis, D., \& Door, V. (2007). The evolution of an effective pedagogy for teachers using the interactive whiteboard and modern languages: An empirical analysis from the secondary sectors. Learning, Media and Technology, 32(1), 5-20. https://doi.org/10.1080/17439880601141146.

Gray, C., Hagger-Vaughan, L., Pilkington, R., \& Tomkins, S. (2005). The pros and cons of interactive whiteboards in relation to the key stage 3 strategy and framework. Language Learning Journal, 32, 38-44. https://doi.org/10.1080/09571730585200171. 
Greenberg, J. H. (1960). Linguistic evidence for the influence of the Kanuri on the Hausa. Journal of African History, 1(2), 205-212. https://doi.org/10.1017/S0021853700001791.

Hall, I., \& Higgins, S. (2005). Primary school students' perceptions of interactive whiteboards. Journal of Computer Assisted learning, 21, 102-117. https://doi.org/10.1111/j.1365-2729.2005.00118.

Koster, S., Volman, M., \& Kuiper, E. (2013). Interactivity with the interactive whiteboard in traditional and innovative primary schools: An exploratory study. Australasian Journal of Educational Technology, 29(4), 480-495.

Landis, J. R., \& Koch, G. G. (1977). The measurement of observer agreement for categorical data. Biometrics, 33(1), 159-174.

Levy P. (2002). Interactive whiteboards in learning and teaching in two Sheffield schools: A developmental study. Retrieved from http://www.shef.ac.uk/eirg/projects/wboards.

Mathews-Aydinli, J., \& Elaziz, F. (2010). Turkish students' and teachers' attitudes toward the use of interactive whiteboards in EFL classrooms. Computer Assisted Language Learning, 23(3), 235-252. https://doi.org/10.1080/09588221003776781.

Meskill, C., \& Anthony, N. (2014). Managing synchronous polyfocality in new media/new learning: Online language educators' instructional strategies. System, 42, 177-188. https://doi.org/10.1016/j.system. 2013.11.005.

Moore, M. (1989). Three types of interaction. American Journal of Distance Education, 3(2), 1-6.

Nagle, J. (1999). Histories of success and failure: Working class students' literacy experiences. Journal of Adolescent \& Adult Literacy, 42(2), 172-185.

Orr, M. (2008). Learner perceptions of interactive whiteboards in EFL classrooms. CALL-EJ Online, 9(2). Retrieved from http://callej.org/journal/9-2/orr.html.

Özyürek, R. (2009). The problems encountered in learning Turkish by foreign students of Turkic origin coming from Turkic states and communities to Turkish universities. Turkish Studies, 4(3), 1819-1862. https://doi.org/10.7827/TurkishStudies.759.

Pallant, J. (2007). SPSS Survival Manual: A step by step guide to data analysis using SPSS for windows (Ver. 15) (3rd ed.). Mc Graw Hill: Open University Press.

Smith, H. J., Higgins, S., Wall, K., \& Miller, J. (2005). Interactive whiteboards: Boon or bandwagon? A critical review of the literature. Journal of Computer Assisted Learning, 21(2), 91-101. https://doi.org/ 10.1111/j.1365-2729.2005.00117.x.

Swan, K., Schenker, J., \& Kratcoski, A. (2008). The effects of the use of interactive whiteboards on student achievement. In J. Luca \& E. Weippl (Eds.), Proceedings of world conference on educational multimedia, hypermedia and telecommunications (pp. 3290-3297). Chesapeake: AACE.

Tozcu, A. (2008). The use of interactive whiteboards in teaching non-roman scripts. Computer Assisted Language Learning, 21(2), 143-166. https://doi.org/10.1080/09588220801943726.

Trivett, N., \& Skillen, J. (1998). Using computer technology to integrate instruction in discipline-specific literacy skills into the curriculum: A case study. In ASCILITE98 Conference Proceedings. Retrieved from http://ascilite.org.au/conferences/wollongong98/asc98-pdf/trivettskillen.pdf.

Türel, Y. K. (2010). Developing teachers' utilization of interactive whiteboards. In D. Gibson \& B. Dodge (Eds.), Proceedings of society for information technology \& teacher education international conference (pp. 3049-3054). Chesapeake: AACE.

Türel, Y. K. (2011a). An interactive whiteboard evaluation survey for university students: Validity and reliability Analyses. e-Journal of New World Sciences Academy, 6(2), 1894-1903.

Türel, Y. K. (2011b). An interactive whiteboard student survey: Development, validity and reliability. Computers \& Education, 57, 2441-2450. https://doi.org/10.1016/j.compedu.2011.07.005.

Türel, Y. K., \& Demirli, C. (2010). Instructional interactive whiteboard materials: Designers' perspectives. Procedia Journal of Social and Behavioral Sciences, 9, 1437-1442. https://doi.org/10.1016/j.sbspro. 2010.12.346.

Venkatesh, V., \& Davis, F. D. (2000). A theoretical extension of the technology acceptance model: Four longitudinal field studies. Management Science, 45(2), 186-204. https://doi.org/10.1287/mnsc.46.2. 186.11926.

Xu, H. L., \& Moloney, R. (2011a). "It makes the whole learning experience better": Student feedback on the use of the interactive whiteboard in learning Chinese at tertiary level. Asian Social Science, 7(11), 20-34. https://doi.org/10.5539/ass.v7n11p20.

Xu, H. L., \& Moloney, R. (2011b). Perceptions of interactive whiteboard pedagogy in the teaching of Chinese language. Australasian Journal of Educational Technology, 27(2), 307-325. 